\title{
Segmented Labour Markets in South Africa
}

\author{
Gary S. Fields \\ Cornell University
}

\section{Labour markets, employment and unemployment}

Labour markets are where labour services are bought and sold. In an employer-employee relationship, the employer buys the labour services of an employee. In a self-employment relationship, an individual buys one's own labour services. Employees include those in the public and private sectors, regular and casual employees, and formal and informal workers. The selfemployed include those operating individual enterprises and those working in household enterprises, be they in urban or rural areas and in agriculture or outside of agriculture. At times, own-account work is used synonymously with self-employment'; other times, own-account work' is used more specifically to denote the self-employed who operate without employees.

Following standard international definitions prescribed by the International Labour Organization and adopted with minor modifications by Statistics South Africa, the South African population breaks down as follows as of the first quarter of 2013 (Stats SA, 2013):

- 13.6 million South Africans are employed;

- 4.6 million South Africans-25.7 per cent of the labour force-are unemployed;

- The expanded unemployment rate is 36.7 per cent.

By international standards, South Africa has an exceptionally high rate of unemployment and an exceptionally low rate of self-employment. Agreement is widespread that the main factors responsible are the underperformance of the formal sector and barriers to entry in the informal sector (e.g. Kingdon and Knight, 2004; Davies and Thurlow, 2009).

\section{Segmented labour markets and stratified labour markets}

The textbook labour market model aggregates all workers, all employers and all sectors of the economy into a single labour market. In this single labour market, workers supply labour, employers demand labour and the rate of pay (termed wage for shorthand) is determined by the intersection of supply and demand.

Segmented labour market analysis proceeds from a different starting point. Workers, employers and sectors are not aggregated together. Rather, two or more labour market segments are identified, the groupings reflecting fundamental differences in how labour supply, labour demand and wage-determination mechanisms operate in different segments. For example, in the South African context, it is meaningful to segment the labour market according to whether or not 
the workers belong to trade unions, and the unions succeed in raising wages, benefits and other working conditions for their employed members above what they otherwise would be. In the unionized segment of the South African labour market, compensation is determined by bargaining or contract extension, and the terms agreed to are extended to all firms in the industry or region irrespective of size. Otherwise, compensation is determined by supply and demand.

This, then, leads to the fundamental characterization of a segmented labour market. Labour markets are segmented when, for workers of a given type (a) some jobs are better than others in terms of wages, benefits and/or other working conditions, and (b) access to the good jobs is rationed, meaning that some workers who would like jobs in the better paying segments and who are capable of performing those jobs are able to get such jobs but others who also would like such jobs and are capable of performing them cannot.

Note the qualifier Tor workers of a given type. What South Africa also has is a stratified labour market - that is, one in which some jobs are better than others, the workers in the better jobs are better-trained and more skilled than the workers in other jobs, the workers in the upper strata could get employed in the lower strata but typically choose not to, and the workers in the lower strata lack the skills to get employed in the upper strata and so are not found there. Readers of this chapter - people like university professors and government officials - belong to the upper stratum, whilst the people who support us by serving us meals and cleaning the offices in which we work belong to the lower stratum.

\section{South Africa's segmented labour market}

What is the evidence that South Africa's labour market is segmented? Here are some of the dimensions.

When in 2002 the University of Cape Town posted an advertisement for gardeners and cleaners, 39,000 persons applied. As it turned out, the university decided to hire only 20 new staff, which they did (Wittenberg, 2002). A straightforward explanation for the huge number of applicants is that UCT was offering better pay and working conditions than these applicants could obtain elsewhere, which is why so many of them applied for employment there.

Large firms and unionized firms pay substantially higher wages than smaller firms and informal employers do, controlling for worker characteristics (e.g. Schultz and Mwabu, 1998; Butcher and Rouse, 2001; see Freeman, 2010 for references to these and other studies).

Labour incomes are higher in some sectors of the South African economy than others, and income change is a function of sector change - for example, regular employment pays more than self-employment or casual employment. But only some of the studies reporting wage differentials have held worker characteristics constant (an example of a study that does is Heintz and Posel, 2008), so that it can be said that workers of the same type earn more in some parts of the labour market than others.

But the finding that some types of employment are better-paying than others does not mean that individual workers necessarily remain fixed in place. The latest data (National Income 
Dynamics Study, 2008 and 2010 waves, summarized in NIDS, 2012) reveal substantial movements of workers between employment statuses (employed, active unemployed and out of the labour force), employment type (regular employment, casual employment and self- employment), employment industry (primary, secondary and tertiary sectors) and geographic locations. The NIDS also reveals significant earnings change alongside significant non-change for individual workers.

\section{The multi-faceted labour market challenges in South Africa}

The unemployed are a target for public policy in South Africa, and rightfully so. However, it is not enough just to be concerned about unemployment, as high as it is in South Africa. The essence of segmented labour market analysis is that some jobs are much better than others, and indeed the evidence reviewed in Section 3 shows this. Thus a second challenge for labour market policy in South Africa is to seek higher wages and better working conditions for workers who have jobs but whose earnings are below a South Africa-specific low-wage line- that is, an amount which, by South African standards, leaves the worker and his/her family in poverty (Kingdon, Sand- efur and Teal, 2006). Research has shown that about half of South Africa s labour force earn less than the low-wage line and that about half of the low-earners are unemployed (defined broadly) whilst the other half earn too little to escape poverty (Bhorat and Leibbrandt, 2001).

A third policy challenge is to address the low labour market earnings of South Africa's self-employed. In some places, self-employment is actively discouraged (e.g. Skinner, 2008). Moreover, when South Africans do engage in self-employment, they earn considerably less than do wage employees, and so constitute a disproportionate number of the poor (Kingdon, Sandefur and Teal, 2006). In the international literature, various policies have been suggested for raising self-employment earnings: designing products to help raise the productivity of the self-employed; adopting a positive policy stance towards the self-employed and avoiding hassling them; providing the poor in agriculture with more to work with; facilitating supplemental off-farm wageemployment and self-employment; making capital available to the poor at affordable rates; building skills and business knowhow; and stimulating microfranchising and microconsignment. All have exhibited successes in other contexts and are worthy of consideration in South Africa.

And fourth, for the young South Africans who have not yet entered the labour market, serious attention needs to be given both to hard skills and to soft skills. (Hard skills are about a person's general ability to perform tasks and specific ability to perform particular tasks. Soft skills

are behavioural competencies which may enhance job performance, career prospects or the quality of ones interactions with others.)

In sum, South Africa faces an enormous employment problem, comprising not only those who are unemployed but also those with low labour market earnings by South African standards. Once the problem is conceived of as more than an unemployment problem, different policy analysis and prescriptions follow. The goal is no longer just to create jobs. The goal is to create good jobs. It is as important to raise the earnings of the working poor as it is to get the poor working. 


\section{Choosing amongst possible policy interventions}

The challenges of South Africa's segmented labour market are many, the resources required to meet these challenges vast, and the resources available to meet these challenges limited relative to the size of the challenges. How are policymakers to choose where best to intervene?

To view labour union bargaining as the continuation of South Africa's liberation struggle and every new union contract as a victory against oppression is to ignore the well- established fact that employers in South Africa hire fewer workers at higher wages than they would have at lower wages. Wage elasticity studies indicate that a 10 per cent increase in wages in South Africa results in a 5 to 7 per cent decrease in employment; see Fourie (2011) for a review of a large number of these. On the other hand, more recent studies (Dinkelman and Ranchhod, 2012; Bhorat, Kanbur and Mayet, 2013) found that the introduction of minimum wage laws in various sectors of the South African economy (retail, domestic work, forestry, security and taxi) produced significant reductions in hours in all sectors but a significant reduction in employment only in agriculture. To maintain in light of the evidence that wages can be raised without causing a reduction in employment and hours is wishful thinking.

Moving forward, the approach I urge for choosing amongst various uses of limited resources is social cost-benefit analysis; for further elaboration, see Fields (2012, Ch. 6). Social cost-benefit analysis asks questions such as:

1. What are the extra social benefits from each possible use of an available budget?

2. What are the extra social costs of each possible use?

3. For each possible use, how do the extra social benefits and extra social costs compare?

4. For which activity is the difference between benefits and costs the greatest?

To decide what to emphasize, it would be best for all interested groups in South Africaemployers, the minority of workers in 'insider' positions, the majority of workers in outsider positions, government officials and concerned citizens - to have a dialogue aimed at setting priorities. South Africa must choose carefully between policies aimed at raising the labour market earnings of the employed and policies that would raise employment by holding down the growth of real wages. That debate is worth having. 


\section{References}

Bhorat, Haroon and Murray Leibbrandt (2001), 'Correlates of Vulnerability in the South African Labour Market', in Haroon Bhorat, Murray Leibbrandt, Muzi Maziya, Servaas van der Berg and Ingrid Woolard (eds), Fighting Poverty: Labour Markets and Inequality in South Africa, Cape Town: University of Cape Town Press.

Bhorat, Haroon, Ravi Kanbur and Natasha Mayet (2013), 'The Impact of Sectoral Minimum Wage Laws on Employment, Wages, and Hours of Work in South Africa, IZA Journal of Labor and Development, 2(1).

Butcher, K. and C. Rouse (2001), 'Wage Effects of Unions and Industrial Councils in South Africa, Industrial and Labor Relations Review, 54(2): 349-74.

Davies, Rob and James Thurlow (2009), 'Formal-Informal Economy Linkages and Unemployment in South Africa, IFPRI Discussion Paper No. 00943, December.

Dinkelman, T. and V. Ranchhod (2012), 'Evidence on the Impact of Minimum Wage Laws in an Informal Sector: Domestic Workers in South Africa, Journal of Development Economics, 99:27-45.

Fields, Gary S. (2012), Working Hard, Working Poor, New York: Oxford University Press.

Fourie, Frederick (2011), 'The South African Unemployment Debate: Three Worlds, Three Discourses?', SALDRU Working Paper No. 63.

Freeman, Richard B. (2010), 'Labor Regulations, Unions, and Social Protection in Developing Countries: Market Distortions or Efficient Institutions?', in Handbook of Development Economics Vol 5, Ch. 70, Amsterdam: Elsevier.

Heintz, James and Dorrit Posel (2008), 'Revisiting Informal Employment and Segmentation in the South African Labour Market', South African Journal of Economics, 76(1): 26-44.

Kingdon, Geeta and John Knight (2004), 'Unemployment in South Africa: The Nature of the Beast', World Development, 32(3): 391-408.

Kingdon, Geeta Justin Sandefur and Francis Teal (2006), 'Labour Market Flexibility, Wages and Incomes in Sub-Saharan Africa in the 1990s', African Development Review, 18(3): 392-427.

National Income Dynamics Study (NIDS) (2012), Wave 2 Overview.

Schultz, T. Paul and Germano Mwabu (1998), 'Labor Unions and the Distribution of Wages and Employment in South Africa, Industrial and Labor Relations Review, 51(4): 680-703. 
Skinner, Caroline (2008), 'The Struggle for the Streets: Processes of Exclusion and Inclusion of Street Vendors in Durban, South Africa', Development Southern Africa 25(2): 247-252.

Statistics South Africa (2013), Quarterly Labour Force Survey: Press Statement, May 6.

Wittenberg, Martin (2002), 'Job Search in South Africa: A Nonparametric Analysis', South African Journal of Economics, 70(8): 1163-97. 